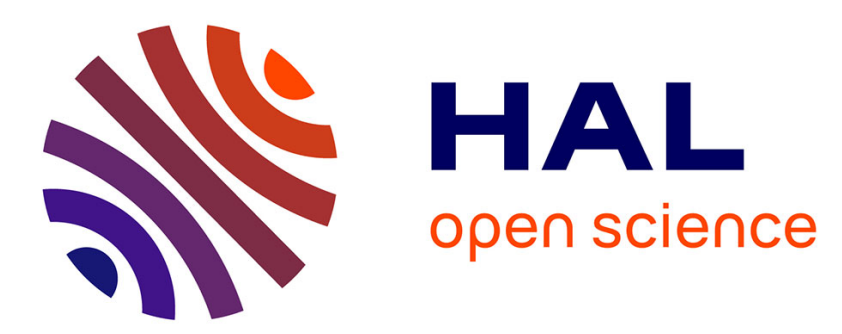

\title{
Stadiums vs fan zones. The influence of attending place on UEFA Euro 2016's host cities' image
}

Christopher Hautbois, Mathieu Djaballah, Michel Desbordes

\section{To cite this version:}

Christopher Hautbois, Mathieu Djaballah, Michel Desbordes. Stadiums vs fan zones. The influence of attending place on UEFA Euro 2016's host cities' image. Soccer and Society, 2020, 21 (5), pp.572-583. 10.1080/14660970.2019.1694006 . hal-03550829

\section{HAL Id: hal-03550829 \\ https://hal.science/hal-03550829}

Submitted on 1 Feb 2022

HAL is a multi-disciplinary open access archive for the deposit and dissemination of scientific research documents, whether they are published or not. The documents may come from teaching and research institutions in France or abroad, or from public or private research centers.
L'archive ouverte pluridisciplinaire HAL, est destinée au dépôt et à la diffusion de documents scientifiques de niveau recherche, publiés ou non, émanant des établissements d'enseignement et de recherche français ou étrangers, des laboratoires publics ou privés. 


\section{Stadiums vs Fan zones. The influence of attending place on UEFA}

\section{Euro 2016's host cities' image.}

Christopher Hautbois*, Mathieu Djaballah*, Michel Desbordes*

*1 - CIAMS, Univ. Paris-Sud, Université Paris-Saclay, 91405 Orsay Cedex, France

2 - CIAMS, Université d'Orléans, 45067, Orléans, France

Abstract

Assessing the potential effects of hosting major sporting events such as FIFA World Cup or

UEFA European Championships on local communities has long been an important source of interest and debate for scholars. Within this field of research, an important set of academic works has been analyzing the relationships between major sporting events and destination branding. The present study aims to move forward in this literature by considering the place where soccer fans attend the competition, namely stadiums and fan zones. Indeed, the vast majority of research works dealing with the effects of sporting events on host cities' image have been limited to stadium spectators. Because fan zones have become an essential component of major sporting - and notably soccer - events, it makes sense for both academics and event managers to explore the perceptions of this new kind of spectators. Hence, the goal of this paper is to analyze the influence of attending place on the image of cities hosting a major sporting event, by comparing the perceptions of stadium and fan zone spectators. The case studied is the UEFA Euro 2016 held in France. An empirical survey was conducted in which data were collected from both stadium and fan zone spectators in Lille and Lyon. A total of 373 usable questionnaires were collected for the analysis. A Principal Component Analysis, Student t-tests and a multiple regression were performed. Findings suggest that several components of city image depend on whether spectators attend the event in stadiums or in fan zones, and that these differences have various effects on spectator satisfaction, leading to new perspectives regarding the use of fan zones to achieve city branding objectives.

\section{Stadiums vs Fan zones. The influence of attending place on UEFA}

\section{Euro 2016's host cities' image.}

Over the last 20 years, cities all over the world have become involved in international competitions; their common goal is to attract visitors, residents and businesses. In general, one can argue that a place with a positive image and reputation is more able to gain attention, resources, people, jobs and money. Consequently, destination ${ }^{1}$ image has become a key element in cities' global strategies. In every case, destination brands have to manage complex relationships between their image or reputation and their identity ${ }^{2}$. For about two decades, one of the "soft" factors that a destination can use in order to build a positive reputation and image is sport, and especially soccer, as it is the most popular sport in the world. Major soccer events can be particularly useful, because they are watched worldwide, putting host territories under the spotlight. For this reason, many cities and countries have bid for soccer events such as FIFA World Cup and UEFA European Championships. The role of sporting events in branding a city, improving image destination or stimulating local economies has been studied in numerous publications ${ }^{3}$. However, almost all these studies only gathered data related to stadium spectators. The original approach of the present study consists in extending the research focus to fan zone spectators - which now tend to surpass stadium spectators in number - in order to compare the influence of attending place on host city image. The case studied is the UEFA Euro 2016 in France, which is one of the world's biggest soccer events. A quantitative survey was conducted in two French cities: Lille and Lyon. A total of 373 usable questionnaires were collected for the analysis (191 in stadiums and 182 in fan zones) in order to compare the influence of attending place on host city image. The paper is structured as follows. First, a brief literature review of major sporting events' impacts on destination image is presented. Then, existing research related to fan zones is drawn upon in order to delineate the research question 
In the third section, the method of this study is described, including the research design, data collection, and data analysis. Finally, the findings are presented and discussed in light of both academic and practical considerations.

\section{Literature review}

Westerbeek et al. ${ }^{4}$ assumed that "increasingly, cities are basing their city marketing efforts around hallmark events in order to maximize the benefits to be achieved from event-driven tourism, sponsorship and media exposure" $\stackrel{5}{-}$. This sporting event-based option - also including participatory events ${ }^{6}-$ which allows cities to be (re)branded, has also been supported by other authors $^{\mathrm{T}}$. The sporting events that draw most attention are the Summer and Winter Olympic Games and the FIFA World Cup. They are reputed to have various kinds of impacts ${ }^{\stackrel{8}{ }}$, regrouped into broader economic ${ }^{9}$ or social categories ${ }^{10}$. With regard to image impacts, one should consider the case of Seoul. This city's branding strategy was designed in parallel with its involvement in international sporting events. Westerbeek et al. mentioned that this process started with the hosting of the 1988 Olympic Games in Seoul, and the 2002 FIFA World Cup in Korea and Japan ${ }^{11}$

\section{Sporting events and destination image}

Bale and Dejonghe ${ }^{12}$ state that the impact of sporting events (in stadiums) on a certain area has been widely covered by geographers. Among other considerations, it has been studied that

hosting $^{113}$ hallmark events is a good way to attract tourists. According to Westerbeek et al. ${ }^{14}$, people are often drawn to destinations because of the hallmark (sporting) events staged there, rather than the region itself. This being said, Chen and Funk ${ }^{15}$ identified 16 image attributes (historical attractions, accommodations, shopping and cleanness of the city, etc...) which are important for sport tourists' intention to revisit the destination. Gibson et al. ${ }^{16}$ studied the relationships between destination image, travel intentions and tourist characteristics. The respondents perceived the Beijing Olympic Games positively and destination image was significantly predictive of the intention to travel to China. With regard to the image of host countries, Lee et al. ${ }^{17}$ clearly demonstrated that hosting this kind of event was associated with a positive impact on tourists' perception of South Korea. Tourists who traveled for the 2002 FIFA World Cup had a more positive image of South Korea, were more satisfied about their experience and had a greater willingness to recommend South Korea to others. These results are in line with Tavakkoli $\stackrel{18}{\text {. }}$. The latter studied host city image related to an international sporting event and predicted spectators' positive word-of-mouth (WOM) towards the city. Liu ${ }^{19}$ found that awareness of sporting events hosted in Shanghai actually depressed the tourism atmosphere and service image of the destination from the non-sports tourists' perspective and thus suggested that the image impact of major sporting events may be different between sports tourists and other tourists.

At the same time, some publications aimed to study destination image in the opposite perspective. -Alonso-Dos-Santos et al. ${ }^{20}$ investigated the influence of destination image on the intention to attend a sporting event. They found that destination image has a weak influence on intention to attend. The main motive of the travel is the event and not enjoying the destination itself. On the other hand, Lee et al. $\frac{21}{}$ mentioned that beside motivation to attend soccer competitions, spectators of the 2002 FIFA World Cup were heavily influenced by their perception that Korea was a safe and secure destination and had interesting and friendly people. Pratt and Chan ${ }^{22}$ found that Hong Kong generation Y' ${ }^{23}{ }^{23}$ interest in attending the 2020 Tokyo Olympics is driven by destination image factors such as being a safe and clean destination. In this study, Japan is perceived as having many historical, cultural and environmental attractions. It has to be noticed that a majority of publications studying the influence of sporting events on destination image deal with sport spectatorship. Few articles ${ }^{24}$ aimed to analyze the influence of participatory events like marathons on destination image. Among them, Funk et al. ${ }^{25}$ revealed 
that participants from dissimilar cultures are more likely to perceive cultural learning as travel benefits, and that women perceived more benefits than men in terms of socialization, relaxation, and cultural learning

Despite this growing academic interest in the role of sporting events regarding cities' marketing strategies, several issues are still to be further explored. For example, are participatory events more or less efficient to boost destination image than spectator sporting events? ${ }^{26}$ What are the links between destination image and event image ${ }^{27} \mathrm{~A}$ specific issue which has not yet been studied in the literature deals with the influence of attending place (namely stadiums vs fan zones) on host city image. Given the ongoing development of fan zones during major sporting events, this issue now appears as an important concern for both academics and managers.

Fan zones: security issues and urbanization of sporting events

Compared to the amount of publications dealing with sporting events from a marketing perspective, fan zones in particular have been little studied over the last 10 years. Fan zones can be more generally called public viewing areas, defined by Haferburg et al..$^{28}$ as installations "offering a televised transmission of a live major s porting event, with enough space to welcome a large number of spectators". These public viewing areas are designed as temporary spaces allowing passionate expressions of fans' involvement. The first large public viewing areas were implemented during 2000 UEFA European Championships and FIFA World Cup in Asia in $2002^{29}$. The first official fan zones were created during the 2006 World Cup in Germany and were declared to be an official and integral part of the tournament in each of the 12 host cities, hence called "FIFA Fanfest". In less than 10 years, public viewing areas have become a major ingredient of mega sporting (and more particularly soccer) events. $\underline{\text { Bale }{ }^{30} \text { described them as a }}$ third spectator environment, somewhere between the stadium and the homes of television viewers. Using an important quantitative survey during the 2008 UEFA European Championships, Schnitzer and Stickdorn ${ }^{31}$ identified the success factors of fan zones. They found important discrepancies in event perception between different stakeholders groups (visitors, event right holders, event organizers). In a broader view, most of the publications investigated fan zones through two main issues: security and the reorganization of public space they engender ${ }^{32}$. Initially, fan zones have been designed as a way to compensate the considerably growing demand for tickets as well as the reduction of the share of available tickets. Fan zones have also been made to better control spectators of an event (including hooligans) who ended up without tickets. As a result, and because emotions cannot be eliminated and fans be silenced, they require a form of channeling: "without supporter enthusiasm and fervor, the event loses its appeal in terms of the ambiance it offers as well as financially. At the same time, the emergence and movement of strong collective emotions- - the euphoria of victory, the disappointment or even rage of defeat — give rise to outbursts that mus be contained without necessarily being repressed" ${ }^{\prime 3}$. This approach refers to the role of surveillance cameras, plain-clothes police officers, security controls at the entrance gate, etc... The central question is finding efficient solutions to provide the same security standards as in stadiums without diminishing the enthusiasm of the fans. A second set of publications analyzed fan zones in their spatial dimension and their ability to rearrange public space. Indeed, before the creation of fan zones, soccer events were spatially limited to the stadium. With the creation of these viewing areas, the boundaries between the event and the urban space are more porous. Berthoud et al. ${ }^{34}$ note that "it is important to see the event not as isolated in time and space but rather as a larger context requiring a temporary recomposition of the city's order". Hagemann ${ }^{35}$ talks about "urbanization of soccer events" on the one hand, and "eventization of the host cities" on the other. From a marketing perspective, this spatial interpenetration presents importan challenges for managers as well as fecund research topics for academics. Indeed, as mentioned at the beginning of this paper, soccer events and host cities are involved in co-branding strategies. From both sides, there is a need to plan the event at the citywide scale. Hence, for 
scholars interested in sport spectators' behavior and destination image, there is a need to take into account that spectator experience of a sporting event no longer depends solely upon what happens in the stadium, but also on the strategic choices regarding fan $z^{2} e^{36}$. In this regard, one can notice that fan zones are not the only alternative place for attending events. Pubs and bars provide another fan experience. As pointed by $\mathrm{Weed}^{37}$ pubs have become a regular venue in which to watch live sport (and particularly soccer) since the end of the 1990's. They notably address two important dimensions of the sport spectating experience: the need for a physica proximity to the event and the importance of the re-telling of the experience of being there $\left(\mathrm{Weed}^{38}\right)$. However, they have been excluded from this research because their experience is not under the responsibility of neither the host cities nor the organizing committee of the event, i.e. beyond the managerial scope of the paper.

Therefore, this study explores the influence of attending place (stadium vs fan zone) on host city image through the case of the UEFA Euro 2016. The idea is that stadiums and fan zones may deliver a different spectator experience. More particularly, fan zones may constitute an opportunity for cities to valorize their image in a more genuine and distinctive manner than $\underline{\text { stadiums, since they can better adjust these areas to their specific objectives. On the other hand, }}$ the stadium experience may be more intense given the proximity of sporting competitions, which are at the heart of the service sought for by spectators. Hence, this study intends to answer two research questions: (1) does city image differ between stadium and fan zone spectators? And (2) do such differences impact spectator satisfaction? In the following sections, we describe the methods designed to measure the components of city image, to compare spectators' perceptions and to determine the effects of city image on spectator satisfaction.

\section{Methods}

Data were collected from spectators of the UEFA Euro 2016, which is one of the biggest sporting events in the world (24 national teams, 2.4 million spectators and 2 billion TV viewers).
Questionnaire and Scale Development

A questionnaire was developed that comprised a section related to city image as well as five other sections (which were not used for this paper). City image questions were adapted from Kaplanidou and $\operatorname{Vogt}^{34}$, including 15 cognitive items covering city infrastructure, accommodations, tourist information, hygiene, safety, cultural events (among others), and measured on a five-point Likert scale (from $1=$ strongly disagree to $5=$ strongly agree), as well as 7 affective items measured on a five-point semantic scale based on differential items (for example $1=$ gloomy to 5 = cheerful - see Table 2 for a presentation of all items). Spectator satisfaction was captured with a single item, namely "I am satisfied with the overall experience of the event in this city", and measured on a five-point Likert scale (from 1 = strongly disagree to $5=$ strongly agree). Additionally, for sample description purpose, the demographics section included five variables: gender, age, household income, education level and country of origin.

\section{Data collection}

UEFA Euro 2016 was held in 10 French cities. Paris was not selected for this study because it is already a well-known city which benefits from an important international audience, and because its image is already well structured. Two medium-sized cities were selected, namely Lille (234.000 of inhabitants, 149th biggest European city) and Lyon (506.000 of inhabitants, 60th biggest European city). They were considered interesting for this research because their international reputation and image are still under construction. Therefore, the UEFA Euro 2016 was a relevant way for them to strengthen their attractiveness and improve their image. An onsite survey was undertaken as detailed in the table below. The gathering of questionnaires was divided into 16 sessions in order to get a representative sample of the spectators attending the competition.

Table 1. Questionnaire distribution.

\begin{tabular}{|c|c|c|c|c|}
\hline Date & City & Match & $\begin{array}{c}\text { Stadium } \\
\text { questionnaires }\end{array}$ & $\begin{array}{c}\text { Fan zones } \\
\text { questionnaires }\end{array}$ \\
\hline
\end{tabular}




\begin{tabular}{|c|c|c|c|c|}
\hline June 13 & Lyon & Belgium-Italy & 18 & l \\
\hline & Lyon & Austria-Hungary & & 12 \\
\hline June 15 & $\begin{array}{l}\text { Lyon } \\
\end{array}$ & $\begin{array}{l}\text { France-Albania } \\
\text { Fance }\end{array}$ & 1 & 15 \\
\hline June 15 & Lille & Russia-Slovakia & 23 & 12 \\
\hline June 16 & Lyon & 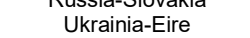 & 23 & 7 \\
\hline June 16 & Lille & Germany-Poland & 21 & 12 \\
\hline June 18 & Lyon & Portugal-Austria & 1 & 21 \\
\hline June 19 & $\begin{array}{l}\text { Lyon } \\
\text { Lyon }\end{array}$ & Roumania-Albania & 27 & ${ }_{1}^{21}$ \\
\hline June 19 & $\begin{array}{l}\text { Lon } \\
\text { Lille }\end{array}$ & Switerzland-France & 22 & 14 \\
\hline June 21 & Lyon & Czech Republic-Turkey & 1 & 9 \\
\hline June 22 & $\begin{array}{l}\text { Lyon } \\
\end{array}$ & Hungary-Portugal & 19 & l \\
\hline June 22 & Lille & Italy-Ireland & 20 & 11 \\
\hline June 25 & Lyon & Croatia-Portugal & 1 & 24 \\
\hline June 27 & Lille & Italy-Spain & 1 & 18 \\
\hline July 1 & Lille & Walles-Belgium & 18 & 13 \\
\hline July 3 & Lille & France-Island & 1 & 14 \\
\hline
\end{tabular}

The survey was administered by 13 trained students from a sport management university in

France. These students were fluent in English. In order to be able to distinguish between stadium and fan zone experience, only stadium spectators who had not been to the fan zone and fan zone spectators who had not been to the stadium were interviewed.

Stadium spectators were asked to answer the questionnaire outside the stadium after the match. Interviewers were located all around the stadium. Every fifth person passing by was intercepted and asked if he/she was willing to answer the questions. Fan zones spectators were interviewed at half-time and after the match, inside the area. Students provided a brief background explanation. Questionnaires were presented to the respondents and they were asked to rate how much they agreed with each item on the scale. For spectators who were neither English nor French speakers, a glossary of important terms in German, Spanish and Italian was at the disposal of students. A total of 724 questionnaires were collected, among which 373 with foreign spectators. Given that the scope of this paper is on international image and reputation, only these latter were used for this study : 198 in Lille, 175 in Lyon, 182 in fan zones and 191 in stadiums. A majority of the spectators were male (67.7\%) and 24-40 years old (55.4\%). 63\% had at least a university entrance diploma. The annual household income, for $35.1 \%$ of the respondents, was between $\$ 20.000$ and $\$ 39.000$ (below $\$ 20.000$ for $24.6 \%$ and between $\$ 40.000$ and $\$ 59.999$ for $28.3 \%$ ). $94.6 \%$ of spectators came from a European country.
Data analysis

Procedures in SPSS 20.0 were utilized to calculate descriptive statistics, to conduct a Principal Component Analysis of city image, t-tests of city image factors between stadium and fan zone spectators as well as a multiple regression of spectator satisfaction on these factors.

\section{Results}

Principle component analysis of city image

A PCA was conducted to identify the latent factor structure and reduce city image items. The Kaiser-Meyer-Olkin (KMO) measure of sampling adequacy value was .871 and Bartlett's Test of Sphericity (BTS) was significant $(\mathrm{p}<.001)$, indicating that the sample was appropriate for a factor analysis ${ }^{40}$. To determine the factors and their associated items, the following criteria were used, based on Kim and Walker ${ }^{41}$ : (a) factors with eigenvalues greater than 1.0, (b) enough factors to meet a specified percentage of variance explained (i.e., usually $60 \%$ or higher), (c) an item with a factor loading equal to or greater than .40 , (d) factors shown by the scree test to have substantial common variance, and (e) an identified factor and retained items which are interpretable in the theoretical context.

The initial 22 items were reduced to 14 under 5 factors meeting the retention criteria, explaining $68 \%$ of the variance. The resultant five factors were labelled: (1) affective image (5 items, $\alpha$ $=.817$ ), (2) hygiene and safety ( 2 items, $\alpha=.733$ ), (3) tourist service ( 3 items, $\alpha=.718$ ), (4) cultural resources ( 2 items, $\alpha=.791$ ), and (5) price ( 2 items, $\alpha=.724$; see Table 2 for factors loadings, Cronbach's Alphas and mean scores of each item). 


\begin{tabular}{|c|c|c|c|c|c|c|c|}
\hline Items and factors & 1 & 2 & 3 & 4 & 5 & $\begin{array}{c}\text { Cronbach } \\
\text { Alphas }\end{array}$ & $\begin{array}{l}\text { Mean } \\
\text { Scores }\end{array}$ \\
\hline City affective image (1) & & & & & & .817 & \\
\hline City locals are friendly & .773 & & & & & & 4.15 \\
\hline According to you, the city is gloomy / cheerful & .760 & & & & & & 4.12 \\
\hline According to you, the city is dull/ exciting & .720 & & & & & & 3.87 \\
\hline According to you, the city is unpleasant / pleasant & .632 & & & & & & 4.11 \\
\hline According to you, the city is distressing / relaxing & .560 & & & & & & 3.74 \\
\hline Hygiene and safety (2) & & & & & & .733 & \\
\hline This city has a good standard of hygiene and cleanliness & & .742 & & & & & 3.79 \\
\hline $\begin{array}{l}\text { This city is safe } \\
\text { and }\end{array}$ & & .788 & & & & & 3.76 \\
\hline City tourist service (3) & & & & & & .718 & \\
\hline This city has suitable accommodations & & & .686 & & & & 3.88 \\
\hline This city has quality infrastructure (roads, airport, utilities) & & & .728 & & & & $\begin{array}{l}4.00 \\
4.05\end{array}$ \\
\hline This sity has a good network of tourist information & & & .638 & & & & 3.70 \\
\hline City cultural resources (4) & & & & & & .791 & \\
\hline This city offers interesting cultural events (animations, entertainments) & & & & .851 & & & 3.87 \\
\hline This sity offers interesting historical attractions (museums and/or art centers) & & & & .802 & & & 3.90 \\
\hline City price (5) & & & & & & .724 & \\
\hline This sity's accommodations are reasonably priced & & & & & .835 & & 3.55 \\
\hline This city is a n inexpensive place to visit & & & & & .842 & & 3.61 \\
\hline
\end{tabular}

Influence of attending place on city image factors (t-tests)

Student $\mathrm{t}$-tests were then performed to look for differences between stadium and fan zone spectators on each of the five factors. In order to do so, mean scores between each factors respective items were calculated ${ }^{42}$. Significant differences were found for two factors, namely cultural resources and price (see Table 3). Both differences were in favor of fan zone spectators, meaning that these spectators seem to be more inclined to notice interesting cultural events and/or historical attractions, and that they perceive local prices more favorably than stadium spectators. Hence, stadium and fan zone experiences appear to generate some differences in city image perception.

\begin{tabular}{|c|c|c|}
\hline Factors & $t$ & Meaning \\
\hline Affective image & ,582 & No difference \\
\hline Hygiene and safety & $-1,922$ & No difference \\
\hline Tourist service & ,832 & No difference \\
\hline Cultural resources & $2,521^{\star \star}$ & Fan zone $>$ stadium \\
\hline Price & $3,523^{* \star *}$ & Fan zone $>$ stadium \\
\hline
\end{tabular}

Multiple regression analysis of spectator satisfaction on attending place and city image predictors

In order to better understand how these differences can impact spectator satisfaction, a standard multiple linear regression analysis was run. Predictors included the five city image factors, the "attending place" variable (stadium vs fan zone), as well as all interactions between attending place and these factors. The context variable "Lille-Lyon", its interactions with the five factors as well as with attending place were also included to check for potential context effects. All predictors were centered, and interactions were calculated based on centered predictors. ${ }^{43}$ 
Table 4 provides the results of the multiple regression. Predictors did not suffer from significant multicollinearity (all VIF $<2.225)$, and the Durbin-Watson test $(\mathrm{d}=1.616)$ was satisfactorily close to 2 and within the upper and the lower bound. ${ }^{44}$ Globally, the regression model predicts only $31 \%$ of the variance in spectators' satisfaction, which can easily been explained by the fact that satisfaction may also depend on many other variables (notably related to the event itself) that were not the focus of this paper.

A first and somewhat surprising finding was that attending place has a direct effect $(\beta=0.102$, $p<0.049$ ) on spectator satisfaction, in favor of fan zones. Given its slight level of significance, this effect has to be taken with caution, especially because it may have numerous lines of explanation (issue of the match, attachment to a national team, weather, etc...) which are beyond the scope of this paper

More significantly, city affective image has an effect $(\beta=0.255, \mathrm{p}<0.000)$ on spectator satisfaction. While previous t-tests showed that there was no significant difference in affective image scores between stadium and fan zone spectators, an interesting finding is that attending place nonetheless appears as a moderator between this predictor and spectator satisfaction ( $\beta=$ $0.139, \mathrm{p}<0.027)$. More specifically, a simple slope analysis ${ }^{45}$ shows that this predictor has a much greater effect on satisfaction for fan zone spectators $(\beta=0.324, p<0.000)$ than for stadium spectators $(\beta=0.097, \mathrm{p}<0.000)$

City cultural resources also has a significant effect $(\beta=0.246, p<0.000)$ on spectator satisfaction. There is no moderator effect of attending place, meaning that this predictor has a comparable effect on satisfaction for both stadium and fan zone spectators. However, since previous t-tests showed that fan zone spectators had higher scores than stadium spectators on this factor, fan zones seem to constitute a more effective way for host cities to work on their cultural image.
City price has a slightly significant effect $(\beta=0.112, p<0.036)$ on spectator satisfaction. In the same way as city cultural resources, there is no moderation with attending place, meaning that this modest effect exists both for fan zone and stadium spectators. Nonetheless, as shown by the t-tests, fan zone spectators have better perceptions on the price dimension than stadium spectators, which seems logical, notably given that fan zones' entrance is free.

The other city image and moderator predictors do not impact spectator satisfaction. It is the same for contextual predictors, what tends to indicate that at least some of these first results may apply to other cities in a relatively stable fashion.

\section{Table 4. Multiple regression analysis of spectator satisfaction.}

\begin{tabular}{|c|c|}
\hline \multirow{3}{*}{$\begin{array}{l}\text { Predictors } \\
\text { City image predictors }\end{array}$} & Spectator satisfaction \\
\hline & $\beta$ \\
\hline &, $255^{\star \star \star}$ \\
\hline Hygiene and safety &, 003 \\
\hline Tourist service &, 076 \\
\hline Cultural resources & $246^{\star \star \star *}$ \\
\hline Price & $112^{*}$ \\
\hline \multicolumn{2}{|c|}{ Attending place predictors and moderators } \\
\hline Attending place & , 102* \\
\hline Affective image * Attending place & $139^{*}$ \\
\hline Hygiene and safety * Attending place &, 068 \\
\hline Tourist service * Attending place & ,085 \\
\hline Cultural resources * Attending place & 038 \\
\hline Price * Attending place & ,039 \\
\hline Contextual predictors and mo & \\
\hline Lille-Lyon &,- 082 \\
\hline Affective image * Lille-Lyon & 086 \\
\hline Hygiene and safety * Lille-Lyon &,- 039 \\
\hline Tourist service * Lille-Lyon &,- 092 \\
\hline Cultural resources * Lille-Lyon &, 002 \\
\hline Price * Lille-Lyon &,- 006 \\
\hline Attending place * Lille-Lyon &,- 036 \\
\hline
\end{tabular}

\section{Discussion}

These results fall within an increasing research area that explores the relationships between major sporting events and destination image. More particularly, it extends previous research works, which try to determine the influence of spectator characteristics on their perceived image 
on the host city and their satisfaction. ${ }^{46}$ In this respect, several findings have to be discussed.

Firstly, two city image dimensions which significantly impact spectator satisfaction - namely cultural resources and price - appear to produce better spectator attitudes in fan zones than in stadiums. Regarding cultural resources, it seems that fan zones are better able to valorize cities' cultural or historical attractions than stadiums. This may be explained, on the one hand, by the fact that fan zones generally take place at the heart of the city, near tourist sites. It was the case both in Lille - where the fan zone was in close proximity to attractions such as the Grand Palais, the Jardin des Géants or the Saint-Maurice Church - and in Lyon - where it was in the Old Lyon neighborhood, near the Hôtel Dieu, the Museum of Printing, the Museum of Decorative Arts or the Jacobins Place. A supplementary explanation may be that fan zones allow more leeway and space for cities to set up cultural attractions. Indeed, both Lille and Lyon developed a variety of animations (concerts, parades, sporting contests, garden parties) in their respective fan zones. This result is thus consistent with Bar-Kolelis et al ${ }^{47}$, who analyzed the use of fan zones for the promotion of two polish cities during the Euro 2012 and showed how the prestigious status and location of these fan zones constituted key elements to valorize city image. Regarding the price dimension, the (slightly significant) difference between stadium and fan zone spectators may be explained by a classical assumption in consumer behavior literature, namely that consumer attitude depends on a comparison between the price and the perceived value of a given product or service. ${ }^{48}$ Hence, as the access to fan zones was free, spectators had probably not the same level of expectation than in stadiums where the prices ranged between 25 and 200 euros in both cities. They consequently stood less chance of being disappointed and more chance that the perceived value of the fan zone experience exceed its costs (transport, food and beverages).

A second part of these findings relates to the moderator role played by attending place on the relationship between affective image and spectator satisfaction. This may suggest that stadium and fan zone spectators' expectations are not only of a different level, but also of a different nature. Indeed, affective image seems to be a more important predictor of satisfaction for fan zone spectators, meaning that these spectators give a particular value to the cheerfulness of the city as well as to the friendliness of locals. This could be due to a greater propensity for fan zones to enable social interactions between spectators, what would make fan zones particularly appropriate places to prompt the feeling of celebration around sporting events, as defined by Chalip ${ }^{49}$ through the notions of liminality and communitas. As a matter of fact, . Uunlike in stadiums, fan zone spectators can move around freely. They may also feel less surveilled. This may lead them to meet locals as well as people from various nationalities, and to participate in festive moments which are different from traditional supporterism. In this way, the energy (called liminality) that is injected into the atmosphere can better be spread outside of preexisting - i.e. friends or relatives - groups, thereby enabling for the forming of a sense of shared emotion (called communitas).

Simultaneously, while the absence of a significant difference around the tourist service dimension is not surprising, since fan zone and stadium spectators do not use separate infrastructures (roads, airports, etc...) or accommodations, the same result is more interesting regarding hygiene and security. It could actually indicate that fan zones can achieve a comparable level of safety and cleanliness than stadiums, what constitutes a major challenge for cities. $\frac{50}{}$

Another last worth discussing point is the direct effect found of attending place on spectator satisfaction, which would mean that fan zone spectators are globally more satisfied than stadium spectators. This result does not necessarily imply that the fan zone experience is "better" than the stadium experience per se. Indeed, this was not part of the research question developed in this paper. In order to answer such a question, many other factors, notably related to the event, should have been taken into account. Furthermore, as this study tends to show that stadium and 
fan zone spectators have different expectations, a blunt comparison of their satisfaction is hard to make. Nonetheless, what can be drawn from this result is that fan zones are not perforce a second-class, consolation prize for people without tickets. It is a genuine experience, from which spectators are able to draw a real satisfaction, as was suggested by Schnitzer and Stickdorn $^{51}$, and a positive image of the host city as pointed out in this paper.

\section{Conclusion}

The present study intends to contribute to the research on major sporting events and destination branding by analyzing the particular role and effects of attending place on host city image. In this regard, findings suggest that the image of cities hosting a major sporting event partly depends on whether spectators attend it in stadiums or in fan zones. Furthermore, these differences between the stadium and the fan zone experience have various effects on spectator satisfaction.

Several limitations have however to be acknowledged, and could serve as a starting point for future research. The most obvious is related to the generalizability of the results, given the three contextual specificities of the present methodology, namely the size of the event (major), the status of the host cities (medium-sized) and the sport (soccer). Hence, future research could challenge these results in other contexts, in order to contribute to a better understanding of the fan zone experience, which is neither comparable to stadiums' nor to TV's forms of spectatorship but has its own factors of satisfaction, as suggested in this paper.

Another limitation is that in this paper, the fan zone experience was opposed to the stadium experience (stadium-only and fan zone-only spectators were interviewed) for comparison purpose, while they often are complementary for sport tourists. Future research may gain in exploring how these experiences combine - along with the experiences of others attending places' like pubs as evoked at the beginning of this article - notably by using approaches based on customer journey ${ }^{52}$. This could improve the predictability of cities' event based tourism strategies, notably by better capturing the determinants of returning intention, which is their main objective $\mathrm{e}^{53}$. Indeed, as perceived image of the host city is an important part of returning intention, research should focus on the identification and the respective influence of the diverse fan experiences that shape this image. Furthermore, as testified by a certain number of respondents to the questionnaires, it seems that a part of sporting events' visitors only go to the fan zones. Obtaining more information on them (motivations, socio-demographics, journey, etc...) would be of use for both academics, event managers and tourism professionals, as they may constitute a new consumer segment. Other avenues may relate to sponsorship issues. As vaster and more adaptable spaces than stadiums, fan zones may give unique opportunities for sponsors to create positive and distinctive relationships with spectators.

More generally, in face of a continuing increasing of major sporting events' hosting costs notably due to the building or renovation of sporting facilities - fan zones can be considered either as complementary or as alternative strategies by cities in order to achieve a better economic impact of major sporting events. An interesting kind of "alternative strategies" has been observed during the UEFA Euro 2016, when French cities like Nantes, Strasbourg, and Rennes, which did not host matches in stadiums, nevertheless set up fan zones in order to attract both locals and tourists. Such strategies have the advantage to generate tourism revenues with much lower public expenses. For all these reasons, research related to fan zones may gain in importance in the sport management literature, because public viewing areas can accommodate many more visitors than stadiums, and because they can play an important role in valorizing city image.

Notes

1. Can be defined as places that have tourism-oriented business.

2. Morgan et al., Destination brands. 
3. Westerbeek et al., 'Key success factors in bidding'; Rein and Shields, 'Place branding sports'; Heslop et al., 'Mega-event and country co-branding'.

4. Westerbeek et al., 'Key success factors in bidding', 309 .

5. Beside the role of sporting events, some authors highlighted the role of football clubs in strengthening a post-national identity in Europe and in promoting european cities in a competition context. Through the example of Manchester, King ('Football fandom and post-national identity in the New Europe') states that United's fans took the opportunity provided by the expansion of the Champion's League and United's playing success to travel more intensely in Europe and to extend beyond UK the specificities of Manchester's social identity.

6. Kaplanidou et al., 'Recurring sport events and destination image'.

7. Rein and Shields, 'Place branding sports'; Heslop et al., 'Mega-event and country cobranding'; Herstein and Berger, 'Much more than sports'.

8. Gratton, Shibli, and Coleman (2006) suggest four main perspectives: economic impact, sports development, media and sponsor evaluation and place marketing effects.

9. Maenning and Zimbalist, International handbook on the economics of mega-sporting events; Preuss and Alfs, 'Attracting major sporting events'

10. Taks, Chalip and Green, 'Impacts and strategic outcomes from non-mega sport events for local communities'

11. See Lee et al., 'The Impact of sport mega-event on destination image'.

12. Bale and Dejonghe, 'Sports Geography: an overview'.

13. Or bidding, since the image of countries can be positively impacted by their involvement in bidding processes for sporting events, regardless of their results. On this matter see Cornelissen, 'Sport mega-events in Africa'.

14. Westerbeek et al., 'Key success factors in bidding'.

15. Chen and Funk, 'Exploring destination image, experience and revisit intention'.

16. Gibson et al. 'Destination image and intent to visit China'.

17. Lee et al., 'The Impact of sport mega-event on destination image'.

18. Tavakkoli, 'Impact of city image, event fit, and word-of-mouth attempt'.

19. Liu, 'Major Sports Events, Destination Image and Intention to Revisit'.

20. Alonso-Dos-Santos et al., 'Destination image of a city hosting sport event'.

21. Lee et al., 'The Impact of sport mega-event on destination image'.

22. Pratt and Chan. 'Destination image and intention to visit the Tokyo 2020 Olympics'.

23. People who were born between 1980 and 2000 .

24. For instance Hallman et al., 'Event image perceptions among'; Kaplanidou and Gibson, 'Predicting behavioral intentions'; Kaplanidou et al., 'Recurring sport events and destination image'.

25. Funk et al., 'International sport event participation'.

26. Derom and Ramshaw, 'Leveraging sport heritage to promote tourism destinations'.

27. Kaplanidou and Vogt, 'Affective event and destination image'.

28. Haferburg et al., 'Public viewing areas: urban interventions', 174

29. Some informal fan zones were organized during past sporting events such as the 1998 World Cup in France. But these kind of fan zones hasn't been considered for this esearch as they were dealing with an embryonic stage of the concept. Moreover, these an zones were not controlled by the UEFA but introduced by some local governing bodies. Some of them were even forbidden by TF1, the official broadcaster of the competition, for France which considered that broadcasting the competition for free was an unfair commercial practice

30. Bale, 'Virtual fandoms'

31. Schnitzer and Stickdorn, 'Key success factors for fan zones'.

32. See Lauss and Szigetvari, 'Governing by fun: EURO 2008'; Klauser, 'The Exemplification of 'Fan Zones',

33. Berthoud et al., 'Euro 2008 in Geneva', 11.

34. Ibid., 12

35. Hagemann, 'From the stadium to the fan zone'.

36. Bar-Kolelis et al., 'Promotion of host cities of Euro 2012'.

37. Weed, 'The pub as a virtual football fandom venue'.

38. Weed, 'Exploring the sport spectator experience'.

39. Kaplanidou and Vogt, 'Affective event and destination image'.

40. See George and Mallery, Discriminant analysis.

41. Kim and Walker, 'Measuring the social impacts'.

42. See Bryman and Cramer, Quantitative data analysis for social scientists.

43. See Aiken and West, Multiple regression.

44. Gujarati and Porter. 'Multicollinearity: What happens'.

45. See Aiken and West, Multiple regression.

46. Funk et al., 'International sport event participation' ; Liu, 'Major Sports Events, Destination Image and Intention to Revisit'.

47. Bar-Kolelis et al., 'Promotion of host cities of Euro 2012'

48. Zeithaml, 'Defining and relating price'.

49. Chalip, 'Towards social leverage of sport events'.

50. Berthoud et al., 'Euro 2008 in Geneva'.

51. Schnitzer and Stickdorn, 'Key success factors for fan zones'.

52. Schnitzer and Stickdorn, 'Key success factors for fan zones'.

52.53. MacCannel, 'Tourist or traveller'

\section{References}

Aiken, Leona S, Stephen G West, and Raymond R Reno. Multiple regression: Testing and interpreting interactions. Sage, 1991. 
Alonso-Dos-Santos, Manuel, Ferran Calabuig, Francisco Montoro, Irena Valantine, and Arunas

Emeljanovas. 'Destination image of a city hosting sport event: effect on sponsorship'.

Transformations in Business \& Economics 13, no. 2 (2014): 161-73.

Bale, John. 'Virtual fandoms: Futurescapes of Football'. In Fanatics: Power, Identity and

Fandom in Football, ed. A Brown, 265-278. London, Routledge, 1998.

Bale, John and Dejonghe, Trudo. 'Editorial. Sports geography: an overview'. Belgeo 2 (2008): 157-166.

Bar-Kolelis, Delia, Boguslaw Gosz, and Tomasz Wiskulski. 'Promotion of host cities of Euro 2012. Case study of Warsaw and Poznan'. Journal of Geography, Politics and Society 1, no. 7 (2014): 43-52.

Berhtoud, Jérôme, Luca Pattaroni, Pascal Viot, and Vincent Kaufman. ‘Euro 2008 in Geneva: A city's experience organizing a large-scale event. Examining 'friendly' fan and hooligan behaviour in the Fan Zone'. International Review on Sport and Violence 3 (2009): 10-16.

Bryman, Alan, and Duncan Cramer. Quantitative data analysis for social scientists. Taylor \& Francis/Routledge, 1990

Chalip, Laurence. 'Towards social leverage of sport events'. Journal of Sport \& Tourism 11, no. 2 (2006): 109-27

Chen, Nan, and Daniel C Funk. 'Exploring destination image, experience and revisit intention: a comparison of sport and non-sport tourist perceptions'. Journal of Sport Tourism 15, no. 3 (2010): 239-59.

Cornelissen, Scarlett. 'Sport mega-events in Africa: processes, impacts and prospects'. Tourism and Hospitality Planning \& Development 1, no. 1 (2004): 39-55.
Derom, Inge, and Gregory Ramshaw. 'Leveraging sport heritage to promote tourism destinations: the case of the Tour of Flanders Cyclo event'. Journal of Sport Tourism 20, no. 3 (2016): 263-83.

Funk, Daniel C, Kristine Toohey, and Tennille Bruun. 'International sport event participation: prior sport involvement, destination image and travel motives'. European Spor Management Quarterly 7, no. 3 (2007): 227-48.

George, Darren, and Paul Mallery. Discriminant analysis. IBM SPSS Statistics, 2007.

Gibson, Heather, Christine Xueqing Qi, and James J Zhang. 'Destination image and intent to visit China and the 2008 Beijing Olympic Games'. Journal of Sport Management 22 (2008): 427-50

Gratton, Chris, Shibli, Simon, and Coleman, Richard. 'The economic impact of major sports events: A review of ten events in the UK'. In Sports mega-events: Social scientific analysis of a global phenomenon, ed. John Horne and Wolfram Manzenreiter, 41-58. Oxford, Blackwell, 2006

Gujarati, Damodar, and Dawn Porter. 'Multicollinearity: What happens if the regressors are correlated'. Basic econometrics (2003): 363-64.

Haferburg, Christoph, Theresa Gorka, and Marie Selter. 'Public viewing areas: urban interventions in the context of mega events'. In Development and Dreams: The urban legacy of the 2010 Soccer World Cup, ed. Udesh Pillay, Richard Tomlison and Orl Bass, 174-99. Cape Town, HSRC Press, 2009.

Hagemann, Anke. 'From the stadium to the fan zone: host cities in a state of emergency'. Soccer \& Society 11, no. 6 (2010): 723-36

Hallmann, Kirstin, Kyriaki Kaplanidou, and Christoph Breuer. 'Event image perceptions among active and passive sport tourists at marathon races: A qualitative and quantitative 
approach'. International Journal of Sports Marketing \& Sponsorship 12, no. 1 (2010): $37-52$.

Herstein, Ram, and Ron Berger. 'Much more than sports: sports events as stimuli for city rebranding'. Journal of Business Strategy 34, no.2 (2013): 38-44.

Heslop, Louise A, John Nadeau, Norm O'Reilly, and Anahit Armenakyan. 'Mega-event and country co-branding: image shifts, transfers and reputational impacts'. Corporate Reputation Review 16, no.1 (2013): 7-33

Kaplanidou, Kyriaki, and Christine Vogt. 'Affective event and destination image: Their influence on Olympic travelers' behavioral intentions'. Event Management 10, no. 2 (2007): 159-73.

Kaplanidou, Kyriaki, and Heather J Gibson. 'Predicting behavioral intentions of active even sport tourists: the case of a small-scale recurring sports event'. Journal of Sport Tourism 15, no. 2 (2010): 163-79.

Kaplanidou, Kyriaki, Jeremy S Jordan, Daniel C Funk, and Lynn L Rindinger. 'Recurring sport events and destination image perceptions: impact on active sport tourist behavioral intentions and place attachment'. Journal of Sport Management 26, no. 3 (2012): 237 48

Kim, Woosoon, and Matthew Walker. 'Measuring the social impacts associated with Super Bowl XLIII: Preliminary development of a psychic income scale'. Sport Management Review 15, no.1 (2012): 91-108.

King, Anthony. 'Football fandom and post-national identity in the New Europe'. The British Journal of Sociology 51, no. 3 (2000): 419-442.
Klauser, Francisco. 'The Exemplification of 'Fan Zones': Mediating Mechanisms in the Reproduction of Best Practices for Security and Branding at Euro 2008'. Urban Studies 48, no.15 (2011): 3203-19

Lauss, Georg, and András Szigetvari. 'Governing by fun: EURO 2008 and the appealing power of fan zones'. Soccer \& Society 11, no. 6 (2010): 737-47.

Lee, Choong-Ki, Tracy Taylor, Yong-Ki Lee, and BongKoo Lee. 'The Impact of sport megaevent on destination image: the case of the 2002 FIFA World Cup Korea/Japan'. International Journal of Hospitality \& Tourism Administration 6, no. 3 (2005): 27-45.

Liu, Dongfeng. 'Major Sports Events, Destination Image and Intention to Revisit: A Perspective of Foreign Tourists'. International Journal of Sports Marketing and Sponsorship 14, no. 3 (2013): 178-89.

MacCannell, Dean, Tourist or Traveller? London: BBC Education, 1996.

Meaning, Wolfgang and Andrew, Zimbalist. International handbook on the economics of mega-sporting events. Cheltenham y Northampton: Edward Elgar, 2012.

Morgan, Nigel, Annette Pritchard, and Roger Pride. Destination brands: Managing place reputation. Routledge, 2011

Pratt, Stephen, and Wai Sum Chan. 'Destination image and intention to visit the Tokyo 2020 Olympics among Hong Kong Generation Y'. Journal of China Tourism Research 12, no. 3-4 (2016): 353-73.

Preuss, Holger, and Christian, Alfs. 'Signaling through the 2008 Beijing Olympics, using mega sport events to change the perception and image of the host'. European Sport Management Quarterly, 11, no 1 (2011): 55-71. 
Rein, Irving, and Ben Shields. 'Place branding sports: strategies for differentiating emerging, transitional, negatively viewed and newly industrialised nations'. Place Branding and Public Diplomacy 3, no. 1 (2007): 73-85.

Schnitzer, Martin, and Marc Stickdorn. 'Key success factors for fan zones (public viewings) covering mega sport events: the case of UEFA EURO 2008 in Austria'. European Journal of Tourism Research 5, no. 1 (2012): 19-37.

Taks, Marijke, Laurence, Chalip and Chris, Green. 'Impacts and strategic outcomes from nonmega sport events for local communities'. European Sport Management Quarterly, 15, no. 1 (2015): 1-6

Tavakkoli, Mohammadhadi. 'Impact of city image, event fit, and word-of-mouth attempt through the host city of an international sporting event'. American Journal of Sports Science 4, no. 6 (2016): 112-19.

Weed, Mike. 'The pub as a virtual football fandom venue: an alternative to 'being there'? Soccer \& Society 8, no. 2-3 (2007): 399-414.

Weed, Mike. 'Exploring the sport spectator experience: virtual football spectatorship in the pub'? Soccer \& Society 9, no. 2 (2008): 189-197.

Westerbeek, Hans M, Paul Turner, and Lynley Ingerson. 'Key success factors in bidding for hallmark sporting events'. International Marketing Review 19, no. 2-3 (2002): 303-22.

Zeithaml, Valarie A. Defining and relating price, perceived quality, and perceived value (report $\mathrm{n}^{\circ}$ 87-101), Cambridge, MA, Marketing Science Institute, 1987. 